\section{Troubled Pleasures: Writing on Politics, Gender and Hedonism}

\section{Kate Soper}

Verso: London, 1990

ISBN $0860913139 £ 32.95 \mathrm{Hbk}$;

ISBN $0860915360 £ 10.95 \mathrm{Pbk}$

It was an act of stealth And troubled pleasure (Wordsworth's Prelude)

Pleasure is troubled. Troubled not only because many of life's pleasures involve aspects of pain and anxiety, or because the conditions within which moments of pleasure are experienced are themselves frequently fraught, but also because many of what were previously simple needs and pleasures (for food, recreation, travel) have become problematic because of the ways in which we satisfy them; ways which are ecologically damaging, morally undesirable, politically unacceptable. For modernity's definition of pleasure is itself problematic: pleasure conceived as individualistic, materialist and narcissistic. This is Soper's assertion. In making it, she is aware that she may be occupying the unpopular and unglamorous position of self-righteous puritanism. As she acknowledges: 'asking others to be troubled by their pleasures . . . is itself troubling'.

Do things not cease to be pleasurable if we must first consider whether they are compatible with the realization of full democracy, social justice and ecological responsibility? Or can we develop new forms of pleasure and sensuality which are, ultimately, less destructive and exploitative, less troubled? And can we do so without appearing to be boring old moralists? Soper wants to argue that we can, and must: and, I think, convincingly and importantly so.

For satisfaction of the pleasures of some impacts on the fulfilment of the needs of others. Discussion of the politics of needs has traditionally fallen into two distinct paradigms, the liberal and the Marxist; the former claiming that individuals must be the arbiters of their own needs; the latter claiming that the needs which people express through purchasing power are not natural, but are false needs generated by the needs of the economy. Neither of these models, claims Soper, is acceptable: for neither draws a distinction between objective and political needs; between basic human requirements (for food, health, shelter, affection) and needs not just for survival, but for human flourishing and happiness.

This becomes of political import in the recognition that we must question current satisfaction of "first world' needs, challenge our patterns of consumption and recognize that only if we begin to enjoy ourselves rather differently can the needs of others begin to be satisfied. Furthermore, argues Soper, if we are to witness a growth in support for socialism, it will be because needs other than those for material consumption have become prominent. But is the questioning of the enjoyments of first-world affluence really about 'need' at all? Surely we are talking not of needs, but of desires?

The epistemological and methodological basis from which Soper raises these questions is the key to understanding their form and resolution. It is a thoughtful basis, delicately drawn among a morass of other, frequently more solid, positions. For Soper maintains a Marxist conviction in the need to reject the capitalist mode of production, but adopts humanist accounts of subjectivity and agency. She has sympathy with the postmodern rejection of the Enlightenment confidence in truth and progress, but draws on phenomenological and existential arguments rather than postmodernist deconstruction, for her conception of subjectivity. Thus it is that she finds more in common with de Beauvoir's perspective of 'in-difference' than 
with the claims of separatism, difference or hyper-individualism so dominant in recent feminist writings. In short, Soper hovers enigmatically between many of the more accepted theoretical positions of the day.

Furthermore, her theoretical stance is grounded in a commitment to philosophical realism and a rejection of those arguments which view language, art or text as constituting a primary realm of human experience. Mapping a path between determinism and radical relativism, Soper wants to adopt a dialetical perspective which perceives us to be part creators of the conditions which also to some extent create us. Hence Soper takes on board the critiques of rationality and objectivity without endorsing the triumph of irrationalism and relativism; she accepts the challenges to previously dominant analyses of power structures without falling into a position of theoretical impotence.

Postmodernist deconstruction has created an agenda in which socialism looks authoritarian in its imposition on subjects and naive in its assumption that such subjects exist. In an effort to rectify this situation, Soper hints at an alternative body of thought, situated between the affirmation of moral autonomy and the powers of historical agency; a tradition of socialist humanism. What these humanists share in common, despite their many differences, is their rejection of deterministic interpretations of historical materialism and of positivistic metaphysics and the stress placed on the active and creative component of human agency.

Soper effectively questions the validity of the Marxist rejection of 'moralism', and asserts the distinction between advocating moralism (assuming that adherence to moral values is in itself sufficient to their realization) and upholding morality. A Marxist humanist morality would involve accepting responsibility not only for how we act individually within a given system, but also for the system itself in which we participate, a 'two-tier' morality. In an age of impending nuclear catastrophe, of massive economic exploitation and ecological destruction, there is something immoral about the refusal to extend the domain of the 'moral' beyond interpersonal relations.

Soper argues for this concern with morality, not only in opposition to a Marxist rejection of moralism, but also in contradistinction to the postmodernist disinterest in ethical issues - a new variation of the longstanding equivocation around issues of morality within left-wing theory. Her claim is that Marxists and poststructuralists alike must acknowledge that their critiques of prevailing rationalities rest on an appeal to subjective freedom, a recognition that selves are not totally determined, that 'there is a self which is in relationship to the world by which it is constructed'. And that there is, therefore, a basis for ethical discussion.

This problematic position of the subject, and of ethical engagement in the world, is also clearly perceptible in feminist theories. Addressing feminism as separatism, as difference and as discourse theory, Soper reveals that autonomy is not the easiest of concepts for feminism to address (see the accusations that de Beauvoir is adopting patriarchal ideology in her stress on independence). Yet humanism, an assertion of sameness, is equally problematic for the 'difference feminists', Irigaray and Cixous, who seem to rule out the possibility of male-female dialogue implicit in de Beauvoir's demand to reconciliation and integration. An alternative to these feminist positions is found in current reworkings of Marxist theory. Habermas, the avowedly modernist critic of postmodernism, offers a critique of instrumental rationality which has much to offer feminist critiques of patriarchal knowledge and power structures. This form of 
feminist theory provides an alternative to all those feminists who were driven, through dissatisfaction with orthodox Marxism's gender-blindness to post-structuralism, to Lacanian psychoanalysis, LeviStrauss's kinship theory, Foucauldian and Derridean 'culturalism'. As Soper states: 'a gender-sensitized Habermasian theory ... must be thought to provide a promising alternative to the Hobson's choice between unreconstructed Marxism, and structuralism/post-structuralist fatalism and nihilism.' What Kate Soper advocates in its place is a two-pronged strategy: the assertion of in-difference and rejection of essentializing discourses, and the retention of the category of 'woman' as a practical political strategy. What we need, claims Soper, is both a humanist and feminist political and moral commitment.

This, I fully accept, may sound to some less like a theoretical grounding that a series of, possibly incompatible, critiques and quibbles. But I, for one, found in this collection a refreshingly coherent concern with issues too long neglected, too frequently marginalized, by the dominant theoretical debates of the day. To assert the importance of morality, of need, of agency, and to place these issues in the context of the array of competing theoretical agendas currently vying for recognition is an illuminating project. It is a brave and difficult position to adopt. Brave because it is open to criticism and scepticism from both the Marxist and the postmodern camps of thought. And difficult because it attempts to salvage elements of each in an, as yet, slightly troubled whole. But this project is motivated less by a desire for theoretical consistency than for the provision of a framework which will enable us to act, to engage with the world in a practical and helpful manner.

And it is perhaps due to this motivation that Soper finds herself feeling ambivalent about theory itself. In this collection she combines essays, reviews, pieces of criticism and fiction. Each with different specific objects of concern, but all with the same fundamental underlying agenda. What gradually emerges is a humanist concern with need and how to satisfy its various manifestations, how to realize the conditions of human flourishing. And there is much to be said for approaching this from different angles, in different genres. For while theoretical work demands a certain form of precision, a clear coherent line of thought, fictional pieces can address issues, play with them, explore their implications, without having a conclusion in mind: one can raise questions without having answers. To cross these disciplinary boundaries; to allow ourselves to write, and therefore to think, in different forms can only help us break through restricting theoretical constraints; allowing ourselves to be open to the implicit illumination of an idea, rather than its explicit evaluation.

It is a joy to find someone rejecting the totalizing solutions offered by the left, while avoiding the nihilistic tendency of postmodernism to opt out of political discourse and action altogether. The voguish indifference to values which has come to dominate theoretical writings in recent years is here firmly rejected in favour of an avowedly ethical concern with social relations.

Judith Squires 